\title{
ANALIZY PRAWNE
}

Tomasz Sienkiewicz

sienkiewicz@kul.pl

Katolicki Uniwersytet Lubelski Jana Pawła II

Wydział Prawa, Prawa Kanonicznego i Administracji

Al. Racławickie 14

20-950 Lublin

\section{Zażalenie na postanowienie o odmowie wszczęcia dochodzenia jako prawna forma działania wojewódzkiego konserwatora zabytków*}

Complaint against the decision on refusal to institute an investigation as a legal form of action of Provincial Monument Conservator

\begin{abstract}
Summary: The legal system functioning in a particular national, organizational, and legal cultural context may have a significant impact on the scope of the protection of monuments. The aim of this paper is to analyse complaints against a decision of a voivodship conservator concerning refusal to initiate an investigation as a legal form of the conservator's activities. While it is common for a perpetrator to have a different legal assessment of an act than the law enforcement agency, it is an entirely different matter when a public authority prosecutor and a law enforcement agency acting as public prosecutor have different views on the prosecution of a case, for example with respect to the scope of application of the clause of insignificant social harm in an act. Beyond the role of a complaint as provided for in the Code of Criminal Procedure, the educational and informative values of taking a formal action are emphasised.
\end{abstract}

\footnotetext{
* Artykuł wydano w ramach realizacji projektu pod tytułem „Prawne formy działania wojewódzkiego konserwatora zabytków" (nr rej. 2015/19/B/HS5/02525), w którym fundatorem badań jest Narodowe Centrum Nauki (National Science Centre, Poland).
} 
Keywords: complaint against a decision on refusal to initiate an investigation, voivodeship inspector of monuments, monuments

Streszczenie: Każdy system prawny ma adresatów norm (np. funkcjonariuszy publicznych) działających w konkretnej krajowej kulturze organizacyjno-prawnej, która może mieć istotny wpływ na zakres ochrony zabytków. Celem niniejszego artykułu jest ukazanie roli zażalenia na postanowienie o odmowie wszczęcia dochodzenia jako prawnej formy działania wojewódzkiego konserwatora zabytków. Sytuacja, w której czyn zabroniony jest różnie oceniany w aspekcie prawnym przez sprawcę czynu i przez organ ścigania, nie budzi raczej powszechnego zdziwienia. Inaczej jest, gdy organ administracji publicznej działający na zasadach przewidzianych dla pokrzywdzonego i oskarżyciela posiłkowego oraz organ ścigania będący oskarżycielem publicznym mają odmienne poglądy na ściganie przestępstwa oraz np. zakres stosowania klauzuli znikomej społecznej szkodliwości czynu. Cele tej instytucji zażalenia wynikają z Kodeksu postępowania karnego, lecz poza tą ustawą znajduje się jeszcze jeden cel działania - cel edukacyjny, cel informacyjny i jest to cel realizowany głównie wobec organów ścigania (Policja, prokuratura), a nie wobec sprawcy przestępstwa.

Słowa kluczowe: zażalenie na postanowienie o odmowie wszczęcia dochodzenia, wojewódzki konserwator zabytków, zabytki

Czy działania na rzecz umacniania tożsamości narodowej są istotne nie tylko dla ustawodawcy, ale również dla organów ścigania? Cechą prawa jest możliwość stosowania przymusu w celu urzeczywistnienia norm prawnych. Działanie bez pozwolenia w dziedzinie ochrony zabytków może spotkać się z sankcjonowaniem w formie przepisów prawa administracyjnego, karnego lub wykroczeń. Jak uważa Lidia Klat-Wertelecka, „relacje prawa administracyjnego z prawem karnym istnieją od dawna i polegają przede wszystkim na umiejscowieniu przepisów prawa karnego w regulacjach administracyjnoprawnych"1. Przymus w ochronie zabytków występuje jako egzekucja administracyjna - zmierzająca do wypełnienia przez zobowiązanego obowiązku, a ponadto represja o charakterze karnym - stanowiąca istotne motywacyjne wzmocnienie chęci wykonania obowiązku przez adresata

1 L. Klat-Wertelecka, Problemy graniczne w postępowaniu egzekucyjnym w administracji, w: S. Wrzosek, M. Domagała, J. Izdebski, T. Stanisławski, (red.), Przegląd dyscyplin badawczych pokrewnych nauce prawa i postępowania administracyjnego. Zjazd Katedr Prawa Administracyjnego i Postępowania Administracyjnego Kazimierz Dolny nad Wisłą, 19-22 września 2010 r., Wydawnictwo KUL, Lublin 2010, s. 223. 
normy². Ustawa z dnia 23 lipca 2003 r. o ochronie zabytków i opiece nad zabytka$\mathrm{mi}^{3}$ (dalej: u.o.z.), zawierając normy o charakterze karnym, sytuuje się w grupie dość restrykcyjnych i na pozór skutecznych mechanizmów prawnych służących wymuszeniu pożądanego zachowania się adresata normy. Bez możliwości przymusowego wyegzekwowania zakazu działania bez pozwolenia nie można mówić o skutecznym działaniu norm w zakresie ochrony zabytków i opieki nad zabytkami. Również administracja publiczna pozbawiona byłaby skutecznego elementu oddziaływania. Jednak w sytuacji, w której organy ścigania nie dokonują czynności, do których zostały powołane, nawet poprawnie skonstruowane normy karne będą bezsilne ${ }^{4}$. Zgodnie z art. 17 § 1 pkt 3 Kodeksu postępowania karnego ${ }^{5}$ (dalej: k.p.k.), nie wszczyna się postępowania, a wszczęte umarza, gdy społeczna szkodliwość czynu jest znikoma. „Przy ocenie stopnia społecznej szkodliwości czynu sąd bierze pod uwagę rodzaj i charakter naruszonego dobra, rozmiary wyrządzonej lub grożącej szkody, sposób i okoliczności popełnienia czynu, wagę naruszonych przez sprawcę obowiązków, jak również postać zamiaru, motywację sprawcy, rodzaj naruszonych reguł ostrożności i stopień ich naruszenia" (art. 115 § 2 Kodeksu karnego', dalej: k.k.). „Nie stanowi przestępstwa czyn zabroniony, którego społeczna szkodliwość jest znikoma" (art. 1 § 2 k.k.). Są to bardzo potrzebne normy, umożliwiające zachowanie elementarnej racjonalności w ściganiu czynów zabronionych (Minima non curat praetor). Natomiast źle się dzieje, gdy klauzula znikomej społecznej szkodliwości (znikomego stopnia społecznej szkodliwości czynu) staje się sposobem na odstąpienie od ścigania przestępstw uznanych przez funkcjonariuszy publicznych za mniej ważne, słowem, gdy staje się środkiem korygowania woli ustawodawcy przez funkcjonariusza publicznego.

Zagrożenie dziedzictwa kulturowego przestępczością nie jest tylko polskim problemem? ${ }^{7}$ Każdy system prawny ma adresatów norm funkcjonujących w konkretnej krajowej kulturze organizacyjno-prawnej, która może mieć istotny wpływ na zakres prawnego egzekwowania ochrony zabytków. Celem niniejszego artykułu jest ukazanie roli tytułowego zażalenia jako instytucji pozwalającej kwestionować nadużywanie przez organy ścigania klauzuli znikomej społecznej szkodliwości (znikomego stopnia społecznej szkodliwości czynu) w przestępstwach związanych z zabytkami. Sytuacja, w której czyn zabroniony jest różnie oceniany w aspekcie prawnym przez sprawcę czynu i przez organ ścigania, nie budzi raczej

\footnotetext{
2 Por. ibidem.

3 Ustawa z dnia 23 lipca 2003 r. o ochronie zabytków i opiece nad zabytkami, tekst jedn. Dz. U. z 2014 r. poz. 1664 ze zm.

4 Por. T. Sienkiewicz, Pozwolenie w ochronie zabytków, Wydawnictwo KUL, Lublin 2013, s. 124 i n.

5 Ustawa z dnia 6 czerwca 1997 r. Kodeks postępowania karnego, tekst jedn. Dz.U.z 2016 r., poz. 1749 ze zm.

6 Ustawa z dnia 6 czerwca 1997 r. Kodeks karny, tekst jedn. Dz. U. z 2016 r., poz. 1137 ze zm.

7 Por. np. O. Jakubowski, Zagrożenie dziedzictwa kulturowego przestępczościq - analiza wydarzeń z 2015 roku, „Santander Art. \& Culture Law Review” 2016, nr 1(2), s. 241-258.
} 


\section{ANALIZY PRAWNE}

Tomasz Sienkiewicz

powszechnego zdziwienia. Inaczej jest w sytuacji, w której dwa organy powołane do ścigania przestępstw mają odmienne poglądy na ściganie przestępstwa oraz zakres stosowania wyżej wskazanej klauzuli. Zamiarem autora niniejszego artykułu jest ukazanie instytucji zażalenia na postanowienie o odmowie wszczęcia dochodzenia jako prawnej formy działania wojewódzkiego konserwatora zabytków. Racje bytu tej instytucji wynikają z Kodeksu postępowania karnego, lecz poza tą ustawą znajduje się jeszcze jeden cel działania - cel edukacyjny, cel informacyjny i jest on realizowany głównie wobec organów ścigania (Policja, prokuratura), a nie wobec sprawcy przestępstwa. Ze zdumieniem należy bowiem odnotować słabą motywację organów ścigania do zwalczania przestępstw wskazanych w ustawie o ochronie zabytków i opiece nad zabytkami. W niniejszym artykule autor posłuży się przykładami z obszaru właściwości Lubelskiego Wojewódzkiego Konserwatora Zabytków (dalej: LWKZ) do zobrazowania swojej tezy.

Dochodzenie jest prowadzone przez Policję lub organy, o których mowa w art. 312 k.p.k., chyba że prowadzi je prokurator (art. 325a k.p.k.) Uprawnienia te przysługują organom Straży Granicznej, Agencji Bezpieczeństwa Wewnętrznego, Krajowej Administracji Skarbowej, Centralnego Biura Antykorupcyjnego oraz Żandarmerii Wojskowej, w zakresie ich właściwości, a także organom wskazanym w przepisach szczególnych (art. 312 k.p.k.). Wśród tych organów nie znalazł się wojewódzki konserwator zabytków i w zakresie skutecznego wszczęcia postępowania karnego jest on najczęściej zależny od innych organów ścigania.

Zgodnie $z$ art. 95 ust. 2 u.o.z.,

Minister właściwy do spraw kultury i ochrony dziedzictwa narodowego lub wojewódzki konserwator zabytków mogą występować na zasadach przewidzianych dla pokrzywdzonego i oskarżyciela posiłkowego w postępowaniu karnym w sprawach dotyczących czynów zabronionych zagrażających ochronie zabytków, dziedzictwu kulturowemu, w tym zbiorom publicznym, restytucji dóbr kultury, w tym zwrotowi dóbr kultury wyprowadzonych z naruszeniem prawa z terytorium Rzeczypospolitej Polskiej, w szczególności czynów określonych w rozdziale 11 [u.o.z.].

W wersji sprzed ostatniej nowelizacji ustawy o ochronie zabytków i opiece nad zabytkami (por. art. 61 ustawy z dnia 25 maja 2017 r. o restytucji narodowych dóbr kultury ${ }^{8}$ ) organy te mogły m.in. występować na prawach oskarżyciela posiłkowego w sprawach karnych. Zmiana wprowadzona wyżej wskazaną ustawą o restytucji narodowych dóbr kultury świadczy o tym, że w kręgu bieżącego zainteresowania ustawodawcy znalazł się status prawny wojewódzkiego konserwatora zabytków w postępowaniu karnym. Świadczy to o aktualności tej tematyki. Upraszczając zagadnienie, można zadać pytanie: czy wprowadzona zmiana w statusie m.in. wojewódzkiego konserwatora zabytków - z możliwości działania „na prawach oskarżyciela posiłkowego” na sformułowanie: „na zasadach przewi-

8 Ustawa z dnia 25 maja 2017 r. o restytucji narodowych dóbr kultury, Dz. U. poz. 1086. 
dzianych dla pokrzywdzonego i oskarżyciela posiłkowego" - spowoduje znaczną modyfikację działania organów ścigania? Bez zmiany kultury organizacyjnej raczej nie ma na to szans, zdaniem autora niniejszego tekstu. Gdyby przestępstwa związane z zabytkami miały być skutecznie ścigane, działoby się to i w poprzedniej wersji przepisu art. 95 u.o.z.

O wpływie kultury organizacyjno-prawnej na stosowanie prawa najlepiej świadczą poszczególne sprawy toczące się przed różnymi organami. Przedstawiony poniżej przykład dotyczy sytuacji, w której nie sprowadzono do Polski w terminie wskazanym w pozwoleniu zabytku wywiezionego na określony czas. Dotyczy to sytuacji, w której uchybienie terminowi określonemu w sposób właściwy dla prawa administracyjnego skutkuje odpowiedzialnością karną. Dysponowanie zabytkiem nie jest pozbawione nadzoru państwowego.

W granicach określonych przez ustawy i zasady współżycia społecznego właściciel może, z wyłączeniem innych osób, korzystać z rzeczy zgodnie ze społeczno-gospodarczym przeznaczeniem swego prawa, w szczególności może pobierać pożytki i inne dochody z rzeczy. W tych samych granicach może rozporządzać rzeczą.

- stanowi Kodeks cywilny ${ }^{9}$ w art. 140. Sytuacja administracyjnoprawna właściciela rzeczy zabytkowej skutkuje ograniczeniami w tym zakresie. Dotyczy to również przemieszczania takiego przedmiotu przez granicę. Wywóz zabytku za granicę jest to czynność faktyczna ${ }^{10}$ podlegająca reglamentacji administracyjnej. Jak wskazuje Monika Drela,

ograniczenia w wywozie za granicę zabytków ruchomych (z natury rzeczy ograniczenia w wywozie za granicę nie dotyczą nieruchomości) dotykają sfery uprawnień właścicielskich określanych jako ius possidendi et disponendi ${ }^{11}$.

Czynności administracji publicznej o charakterze reglamentacyjnym i policyjnym w zakresie przemieszczania zabytków przez granicę znajdują swoje uzasadnienie prawne w Konstytucji Rzeczypospolitej Polskiej ${ }^{12}$ (dalej: Konstytucja RP). Zgodnie z jej art. 5, Rzeczpospolita Polska strzeże dziedzictwa narodowego. Z tego powodu organy ochrony zabytków wyposażone zostały w kompetencje do "strzeżenia", wyrażające się we władczej ingerencji w uprawnienia właściciela lub posiadacza zabytku w sytuacji, gdy czasowo lub na stałe wywozi zabytek za granicę. Funkcja ochronna realizowana jest dla dobra wspólnego, dla

\footnotetext{
9 Ustawa z dnia 23 kwietnia 1964 r. Kodeks cywilny, Dz. U. z 2016 r., poz. 380 ze zm.

10 Por. W. Paczuski, Wywóz zabytku za granicę, w: K. Zeidler (red.), Leksykon prawa ochrony zabytków, 100 podstawowych pojęć, C.H. Beck, Warszawa 2010, s. 409.

11 M. Drela, Własność zabytków, C.H. Beck, Warszawa 2006, s. 229. Por. A. Jagielska-Burduk, Zabytek ruchomy, Wolters Kluwer Polska, Warszawa 2011, s. 175 - „Własność zabytków kształtują nie tylko normy prawa rzeczowego, lecz przede wszystkim regulacje prawa ochrony zabytków".

12 Ustawa z dnia 2 kwietnia 1997 r. Konstytucja Rzeczypospolitej Polskiej, Dz. U. Nr 78, poz. 483 ze zm.
} 
urzeczywistnienia interesu społecznego wyrażającego się w zachowaniu dla przyszłych pokoleń dziedzictwa kulturowego ${ }^{13}$.

Lubelski Wojewódzki Konserwator Zabytków złożył do Prokuratora Rejonowego w Świdniku (na podstawie art. 306 § 1 pkt 2 k.p.k.) zażalenie na postanowienie o odmowie wszczęcia dochodzenia ${ }^{14}$. Wniósł o dalsze prowadzenie postępowania karnego w sprawie dotyczącej niesprowadzenia do Polski śmigłowca w okresie ważności pozwolenia ${ }^{15}$, którego ważność minęła z dniem 12 października 2015 r. Zaskarżonym czynnościom zarzucił naruszenie zasady prawdy materialnej oraz wadliwą ocenę stanu faktycznego i prawnego, polegającą na przyjęciu, że niesprowadzenie zabytku do Polski w okresie wskazanym w pozwoleniu stanowi czyn o znikomej szkodliwości społecznej.

Sprawa została zainicjowana w niestandardowy sposób - otóż przedsiębiorstwo zobowiązane do przywiezienia śmigłowca na teren Polski zawiadomiło LWKZ o tym, że nie przywiozło zabytku w terminie wskazanym w pozwoleniu i wskazało m.in. przyczyny powodujące ww. uchybienie ${ }^{16}$. LWKZ w odpowiedzi poinformował to przedsiębiorstwo o obowiązujących przepisach prawa ${ }^{17}$. Następnie, w związku z obowiązkiem wskazanym w art. 304 k.p.k., pismem z dnia 9.11.2015 r. LKWZ zawiadomił Prokuraturę Rejonową w Świdniku o podejrzeniu popełnienia przestępstwa określonego w art. 109 u.o.z. Art. 109 ust. 1 u.o.z. stanowił wówczas: „Kto bez pozwolenia wywozi zabytek za granicę lub po wywiezieniu go za granicę nie sprowadza do kraju w okresie ważności pozwolenia, podlega karze pozbawienia wolności od 3 miesięcy do lat 5" (obecnie brzmienie przepisu jest znowelizowane ${ }^{18}$ ).

13 Por. K. Zalasińska, Prawna ochrona zabytków nieruchomych w Polsce, Wolters Kluwer Polska, Warszawa 2010, s. 141.

14 Zażalenie LWKZ na postanowienie o odmowie wszczęcia dochodzenia do Prokuratora Rejonowego w Świdniku z dnia 21.12.2015 r., znak: IR.5175.7.3.2015, niepublikowane.

15 Jednorazowe pozwolenie na czasowy wywóz zabytku za granicę nr 3/2012, z dnia 12.10.2012 r., znak IR.5175.4.1.2012, wydane przez LWKZ, niepublikowane.

16 Zob. Zawiadomienie o podejrzeniu przestępstwa ściganego z urzędu skierowane przez LWKZ do Prokuratury Rejonowej w Świdniku z dnia 9.11.2015 r., znak: IR.5175.7.1.2015, niepublikowane.

17 Pismo LWKZ z dnia 9.11.2015 r., znak: IR.5175.7.2.2015, niepublikowane.

18 Art. 109. 1. [u.o.z.] Kto bez pozwolenia wywozi zabytek za granicę albo po wywiezieniu go za granicę nie przywozi na terytorium Rzeczypospolitej Polskiej w okresie ważności pozwolenia albo, w przypadku o którym mowa w art. 56a ust. 8, w terminie 60 dni od dnia, w którym decyzja o odmowie wydania kolejnego pozwolenia na czasowy wywóz zabytku za granicę stała się ostateczna albo od dnia otrzymania informacji o pozostawieniu wniosku o wydanie kolejnego pozwolenia na czasowy wywóz zabytku za granicę bez rozpatrzenia, podlega karze pozbawienia wolności od 3 miesięcy do lat 5 .

2. Jeżeli sprawca czynu określonego w ust. 1 działa nieumyślnie, podlega grzywnie, karze ograniczenia wolności albo pozbawienia wolności do lat 2.

3. W razie skazania za przestępstwo określone w ust. 1 sąd orzeka, a w razie skazania za przestępstwo określone w ust. 2 sąd może orzec, nawiązkę na wskazany cel społeczny związany z opieką nad zabytkami w wysokości od trzykrotnego do trzydziestokrotnego minimalnego wynagrodzenia.

4. Sąd może orzec przepadek zabytku, chociażby nie stanowił on własności sprawcy. 
Komenda Powiatowa Policji Świdnik wydała postanowienie z dnia 15.12.2015 r. o odmowie wszczęcia dochodzenia ${ }^{19}$ "wobec znikomego stopnia społecznej szkodliwości czynu, na zasadzie art. 17 § 1 pkt 3 kpk w zw. z art. 1 § 2 kk". Wcześniej wzywano pracownika Wojewódzkiego Urzędu Ochrony Zabytków w Lublinie do stawiennictwa celem przesłuchania w charakterze świadka ${ }^{20}$.

Na etapie złożenia zażalenia na wyżej wskazane postanowienie ujawnia się różnica stanowisk między wojewódzkim konserwatorem zabytków a Policją. W ocenie LWKZ wyrażenie poglądu, że niesprowadzenie zabytku do Polski w okresie wskazanym w pozwoleniu stanowi czyn o znikomej szkodliwości społecznej ${ }^{21}$, budzi wątpliwości co do prowadzenia wyżej przywołanych czynności, zgodnie z zasadą prawdy materialnej. Zasada prawdy obiektywnej wyraża konieczność dążenia do ustalenia w postępowaniu rzeczywistości takiej, jaką ona była, dążenia do ustalenia rzeczywistych faktów w danej sprawie i wydanie na tej podstawie orzeczenia. Podstawę wszelkich rozstrzygnięć stanowić powinny prawdziwe ustalenia faktyczne, również w ocenie stopnia społecznej szkodliwości czynu. Ocenie powinno być poddane także to, czy zabytek został sprowadzony do kraju wskutek działań podjętych dobrowolnie i terminowo przez podmiot zobowiązany do sprowadzenia zabytku na terytorium Polski, czy też sprowadzenie zabytku do kraju było skutkiem wszczęcia postępowania karnego w sprawie przestępstwa określonego w art. 109 u.o.z.

Zdaniem LWKZ, zgodnie z art. 4 u.o.z., ochrona zabytków polega m.in. na przeciwdziałaniu nielegalnemu wywozowi ich za granicę. Ochrona w wymiarze prawnym realizowana jest także poprzez sankcje karne wskazane w tej ustawie. Rezygnacja ze ścigania w sytuacji niesprowadzenia $w$ terminie wskazanym w pozwoleniu zabytku (śmigłowca) pozbawia normy prawne ich oddziaływania społecznego w pożądanym przez ustawodawcę kierunku. Strzeżenie dziedzictwa narodowego jest obowiązkiem, do wykonania którego zobowiązuje administrację publiczną Konstytucja RP w art. 5. Z samej definicji zabytku wskazanej w art. 3 pkt 1 u.o.z. wynika, że zachowanie jego „leży w interesie społecznym ze względu na posiadaną wartość historyczną, artystyczną lub naukową". Wartość tę potwierdza również cel wywozu śmigłowca, określony we wniosku o wydanie jednorazowego pozwolenia na czasowy wywóz zabytku za granicę (w celach „wystawienniczych”). Miał on być udostępniony jako eksponat muzealny w związku z dziesięcioleciem istnienia jednego z muzeów poza granicami Polski²2 ${ }^{22}$ Śmigłowiec będący przedmiotem wywo-

19 Postanowienie o odmowie wszczęcia dochodzenia wydane przez Komendę Powiatową Policji Świdnik z dnia 15.12.2015 r., RCS-571-15, znak: Ds. 2029/15, niepublikowane; por. zawiadomienie Prokuratury Rejonowej w Świdniku z dnia 31.12.2015 r., skierowane do LWKZ, znak: Ds. 2238/15, niepublikowane.

20 Pismo Komisariatu I Policji w Lublinie do Wojewódzkiego Urzędu Ochrony Zabytków w Lublinie z dnia 19.11.2015 r., L.Dz. 11577/15, niepublikowane.

21 Zob. uzasadnienie postanowienia o odmowie wszczęcia dochodzenia wydane przez Komendę Powiatową Policji Świdnik z dnia 15.12.2015 r., RCS-571/15, Ds. 2029/15.

22 Por. jednorazowe pozwolenie na czasowy wywóz zabytku za granicę nr 3/2012, z dnia 12.10.2012 r., znak IR.5175.4.1.2012, uzasadnienie wydane przez LWKZ, niepublikowane. 


\section{ANALIZY PRAWNE}

Tomasz Sienkiewicz

zu został, mimo wszystko, sprowadzony do kraju (oględziny w dniu 17.12 .2015 r.), lecz okres ważności pozwolenia upłynął z dniem 12.10.2015 r. i LWKZ nie znalazł podstaw do przyjęcia, że zabytek znalazł się na terytorium Polski w okresie ważności pozwolenia. W związku z tym, że znamiona czynu zabronionego wydawały się wypełnione, przedmiot wywozu miał wartość i materialną, i historyczną (mimo że nie był wpisany do rejestru zabytków), w pozwoleniu wskazano skutki prawne niesprowadzenia zabytku na teren Polski w terminie wskazanym w pozwoleniu. Zaistnienie tu znikomego stopnia społecznej szkodliwości czynu wzbudziło wątpliwości LWKZ, wyrażone w zażaleniu na postanowienie o odmowie wszczęcia dochodzenia (zob. przypis 14). Jedną z obiekcji wyrażono zagadnieniem. Jeżeli niesprowadzenie do Polski w okresie ważności pozwolenia takiego zabytku jak śmigłowiec uznawane jest za czyn o znikomej społecznej szkodliwości, to pojawia się pytanie, czy przy takiej interpretacji wskazane w art. 109 u.o.z. przestępstwo ścigane z urzędu (a nie wykroczenie) w ogóle może być ścigane, gdy podmiot zobowiązany sprowadza zabytek do kraju z naruszeniem okresu wskazanego w pozwoleniu. Wydaje się, że intencją ustawodawcy było takie ukształtowanie sytuacji prawnej posiadacza zabytku, by przy czasowym wywozie zabytku sprowadzał go terminowo do Polski, bez motywowania go do tego przez czynności np. LWKZ i prokuratury.

Wydaje się, że ustawodawca celowo włączył ten czyn do katalogu przestępstw, a nie wykroczeń, żeby zaakcentować zasadę przechowywania zabytków należących do polskiego dziedzictwa narodowego na terytorium Polski. Szkodliwość społeczna występuje nie tylko w sytuacji, gdy wbrew pozwoleniu zabytek w ogóle pozostał za granicami naszego kraju. Szkodliwość społeczna w tej sprawie wyraża się, zdaniem LWKZ, m.in. w braku należytej staranności podmiotu dokonującego wywozu zabytku przy zapewnieniu warunków organizacyjnych powrotu zabytku na terytorium Polski w okresie wskazanym w pozwoleniu, co skutkuje działaniem z naruszeniem terminu. Warto wskazać, że ustawa o ochronie zabytków i opiece nad zabytkami nie pozwalała LWKZ w ówczesnym stanie prawnym na określenie terminu wywozu na okres dłuższy niż 3 lata i LWKZ nie mógł go w żaden sposób przedłużyć, nawet w wyjątkowych przypadkach. Maksymalny okres, na jaki można wywieźć zabytek poza granice Polski na podstawie jednorazowego pozwolenia na czasowy wywóz zabytku za granicę, nie zależał od woli LWKZ, ale został wskazany przez ustawodawcę w art. 53 ust. 2 u.o.z. Termin ważności jednorazowego pozwolenia na czasowy wywóz zabytku za granicę nie mógł być dłuższy niż 3 lata od dnia wydania tego pozwolenia ${ }^{23}$. Norma karna zatem chroni przede wszystkim termin określony ustawowo, a nie tylko termin określany przez organ administracji publicznej. W wyżej wymienionym pozwoleniu $\mathrm{nr} 3 / 2012$ wskazano termin ważności pozwolenia w sposób maksymalny (12.10.2012-12.10.2015), więc w ocenie LWKZ podmiot zobowiązany do przywozu zabytku na teren Polski miał wystarczającą ilość czasu, by zorganizować przywóz za-

${ }_{23}$ Obecnie zasada ta jest utrzymana w art. 53 ust 2 u.o.z., lecz wyjątkowe „faktyczne” przedłużenia terminu por. art. 56a u.o.z. 
bytku tak, aby nie przekraczać tego terminu. Z tych powodów zastosowanie w tym przypadku klauzuli znikomej szkodliwości społecznej budziło wątpliwości LWKZ.

Następnie ujawnia się różnica zdań pomiędzy prokuratorem a wojewódzkim konserwatorem zabytków. Sekretariat Prokuratury Rejonowej w Świdniku zawiadomił LWKZ, że prokurator tutejszej prokuratury w dniu 31.12.2015 r., po zapoznaniu się z treścią zażalenia złożonego przez LWKZ „postanowił nie uwzględnić zażalenia i przesłać do Sądu Rejonowego Lublin-Wschód w Lublinie z/s w Świdniku celem rozpoznania"24. Zadziwiającą argumentację przytoczył sąd, podtrzymując stanowisko prokuratora. Nie odniósł się on do ustawowych przesłanek zaistnienia przestępstwa, lecz zastosował tak naprawdę swoiste przedwczesne „nadzwyczajne złagodzenie kary". W uzasadnieniu postanowienia sądu utrzymującego zaskarżone postanowienie w mocy można przeczytać m.in., że:

Dokonując oceny zachowania przedstawicieli firmy [...] w kontekście znikomego stopnia społecznej szkodliwości czynu, należało mieć na uwadze fakt, iż działaniu wymienionych nie towarzyszyło szczególne nasilenie złej woli. Analiza korespondencji e-mail wskazuje, że osoby odpowiedzialne za sprowadzenie śmigłowca z [...] do Polski już we wrześniu 2015 roku podjęły kroki mające na celu wykonanie transportu. Z uwagi na niespodziewane problemy z właściwym zabezpieczeniem transportu i odpowiednimi urządzeniami, doszło do opóźnienia w dokonaniu czynności, o czym zresztą firma poinformowała konserwatora zabytków z własnej inicjatywy. Wskazać należy, że zachowanie pracowników przedsiębiorstwa nie spowodowało realnej szkody, ostatecznie termin sprowadzenia śmigłowca przedłużony został o niespełna dwa miesiące ${ }^{25}$.

W świetle ustawowych przesłanek zaistnienia przestępstwa, do którego wystarczy uchybienie terminu, argumentacja sądu może budzić zastrzeżenia, tym bardziej że przedmiotem oceny jest tu sam sformalizowany początek (i koniec) działania w sprawie - postanowienie o odmowie wszczęcia dochodzenia. Uznano za zasadną odmowę nawet wszczęcia postępowania. Sąd stwierdza w wyżej wymienionym uzasadnieniu, że „decyzję prokuratora należy uznać za słuszną i nie budzącą wątpliwości tak pod względem formalnym, jak i merytorycznym". Sąd ma prawo do niezawisłej oceny, a przedstawiciele doktryny mają prawo do naukowej analizy oceny sądu. Nie odnosząc się do tego konkretnego rozstrzygnięcia, trzeba zadać pytanie: $z$ jakiego powodu ustawodawca zdecydował się na karanie osób przekraczających ten termin? Czy dobra kultury ${ }^{26}$ mają znaczenie dla społeczeń-

24 Zawiadomienie Prokuratury Rejonowej w Świdniku z dnia 31.12.2015 r., skierowane do LWKZ, znak: Ds. 2238/15, niepublikowane.

25 Postanowienie z dnia 3.03.2016 r. Sądu Rejonowego Lublin-Wschód w Lublinie II Wydział Karny z siedzibą w Świdniku, sygn. akt II Kp 13/16, niepublikowane.

26 Antoni Dębiński tak definiuje dobro kultury: „W szerokim rozumieniu, przez to (niejednoznaczne) pojęcie rozumie się wytwory materialne i duchowe oraz wzory zachowań danej społeczności mające znaczenie dla tożsamości i ciągłości rozwoju społecznego, kulturalnego i politycznego; w takim ujęciu oznacza ono praktycznie wszystko to, co jest przekazywane z pokolenia na pokolenie i obejmuje szeroki krąg zjawisk, zachowań i wytworów społecznych, w zasadzie cały dorobek kulturowy minionych generacji, 
stwa na tyle istotne, że uchybienie terminowi w tym zakresie powoduje zastosowanie sankcji karnych? W tym miejscu - nie wiążąc tego z tym konkretnym postanowieniem - warto odnotować zależność przekonania funkcjonariuszy Policji oraz prokuratorów i sędziów o zasadności ścigania i skuteczności działania organów ścigania w zakresie ochrony zabytków. Andrzej Zoll napisał:

Jest sprawą bezsporną, że ustawodawca wprowadza sankcję za popełnienie czynów określonego typu z uwagi na to, że czyny takie godzą w chronione porządkiem prawnym (normy sankcjonowane) dobra. Z punktu widzenia przyjętych przez ustawodawcę założeń aksjologicznych czyny takie, już w sensie kategorialnym, są społecznie szkodliwe. Niewątpliwie więc racją ujęcia w ustawie karnej określonego typu zachowań jako czynów zabronionych pod groźbą kary jest rozpoznana przez ustawodawcę ich społeczna szkodliwość. W procesie stosowania prawa sędzia w zasadzie nie może badać racji uznania zachowań określonego typu za zabronione pod groźbą kary. Nie może badać w szczególności, czy dany typ zachowań realizujących znamiona określone w ustawie jest społecznie szkodliwy. Badanie przez sędziego, czy zachowania danego typu uznane przez ustawodawcę za przestępne są w rzeczywistości społecznie szkodliwe, byłoby wkraczaniem władzy sądowniczej w zakres pozostawiony władzy ustawodawczej ${ }^{27}$.

Udzielenie przez ustawodawcę upoważnienia do działania w ochronie zabytków konkretnym organom ścigania i organom administracji publicznej dokonywane jest w konkretnym celu. Stosowanie czynności policyjnych przez administrację publiczną nie może być sprzeczne z zasadą proporcjonalności i zasadą celowości. Zdaniem Jerzego Supernata:

Wybór skutecznego instrumentu działania administracji publicznej wymaga czegoś więcej niż tylko dokonania przeglądu i oceny wszystkich możliwych instrumentów realizacji danego zadania, o ile taki przegląd jest w ogóle możliwy. Wymaga on jeszcze wiedzy na temat dostosowania instrumentu działania do zadania w istniejących warunkach działania administracji publicznej28.

Najskuteczniejsze działanie w ramach prawa to takie działanie, w którym adresat normy wykonuje jej dyspozycję, bez konieczności stosowania sankcji. Najle-

ogół wartości odziedziczonych po poprzednich pokoleniach" (A. Dębiński, Prawo rzymskie jako podstawa kultury europejskiej, w: A. Dębiński, L. Pietraszko (red.), Ochrona dziedzictwa kulturowego i materialnego pogranicza, Wydawnictwo KUL, Lublin 2011, s. 29-30). Obecnie jest to pojęcie zdefiniowane ustawowo. Zgodnie z art. 2 pkt 1 ustawy z dnia 25 maja 2017 r. o restytucji narodowych dóbr kultury (Dz. U. poz. 1086), „dobro kultury - zabytek w rozumieniu art. 3 pkt 1 ustawy z dnia 23 lipca 2003 r. o ochronie zabytków i opiece nad zabytkami (Dz. U. z 2014 r. poz. 1446 ze zm.), rzecz ruchomą niebędącą zabytkiem, a także ich części składowe lub zespoły, których zachowanie leży w interesie społecznym ze względu na ich wartość artystyczną, historyczną lub naukową, lub ze względu na ich znaczenie dla dziedzictwa i rozwoju kulturalnego".

27 A. Zoll, Komentarz do art. 1 Kodeksu karnego. Stan prawny 1.08.2016 r., LEX [dostęp: 22.04.2017].

28 J. Supernat, Instrumenty działania administracji publicznej. Studium z nauki administracji, Kolonia Limited, Wrocław 2003, s. 135. 
piej jest, gdy adresat normy rozumie jej cel i identyfikuje swoje oczekiwania z tym celem, słowem, jest przekonany o słuszności normy. Najgorzej jest, gdy brak jest akceptacji normy prawnej, a do tego jeszcze sankcja jest nieskutecznym motywatorem. Wówczas cały system jest niesprawny, a aparat administracyjny nie jest w stanie wymusić pożądanego przez prawo zachowania na większości społeczeństwa. „Przyjmuje się, że sprawność zawsze jest wypadkową czynnika ludzkiego i prawidłowej budowy systemu"29 - zauważa Jan Łukasiewicz.

Należy zwrócić uwagę, że samo powierzenie zadań do realizacji jakiejś strukturze publicznej nie wystarczy do skutecznego przeprowadzenia zadania. Jeśli struktura administracyjna, która jest umocowana w konkretnej społeczności uznającej konkretne wartości (a tak tu traktuję, jako strukturę administracyjną i społeczną i Policję, i prokuratury, i sądy), nie jest przygotowana do wykonania zadania lub nie utożsamia własnych celów działania z celem postawionym przez ustawodawcę, natychmiast rozpocznie się próba poszukiwania wyjścia z niewygodnej sytuacji, aby zachowując pozór legalności działania, uniknąć realizowania celu postawionego przez ustawodawcę.

Jeżeli strzeżenie dziedzictwa narodowego, ochrona zabytków i związane z tym umacnianie tożsamości narodowej nie będzie postrzegane jako wartość nadająca się do karnoprawnej ochrony, przepisy ustawy o ochronie zabytków będą bezsilne. Poziom zrozumienia idei ochrony zabytków wśród funkcjonariuszy organów ścigania może czasem budzić wątpliwości i warto byłoby przeprowadzić anonimowe badania w celu poznania prawdziwych poglądów tej grupy społecznej na zasadność karnoprawnej ochrony zabytków. Absolutnie nie wolno dokonywać generalizacji, gdyż można byłoby zrobić krzywdę tym osobom, które widzą potrzebę karnoprawnej ochrony dóbr kultury. Wydaje się jednak, że problem może występować i wymaga dogłębnej analizy, nie tylko prawnej. Autor niniejszego artykułu jest przeciwnikiem przesadnej penalizacji życia społecznego, ale z drugiej strony sytuacja, w której znikoma szkodliwość społeczna może stawać się sposobem na uniknięcie pracy dochodzeniowo-śledczej oraz swoistą nieuprawnioną korektą woli ustawodawcy, budzi sprzeciw ${ }^{30}$. Sąd ma prawo (wskutek wniesienia zażalenia) do rozstrzygnięcia, czy odmowa wszczęcia dochodzenia jest zasadna,

\footnotetext{
29 J. Łukasiewicz, Prawne uwarunkowania skuteczności działania administracji publicznej, Wydawnictwo UMCS, Lublin 1990, s. 21-22.

30 Problem z nieprawidłowym stosowaniem klauzuli znikomej społecznej szkodliwości w sprawach dotyczących pozakodeksowych przestępstw związanych z zabytkami zauważany jest również przez innych badaczy. „Już na wstępie należy przyjąć, że w praktyce umarzanie postępowań w sprawach przestępstw przeciwko dziedzictwu kultury za względu na niską społeczną szkodliwość czynu było raczej «wytrychem», pozwalającym organom wymiaru sprawiedliwości «pozbywać się» uciążliwych i kłopotliwych postępowań, korzystając z niedookreślonego pojęcia językowego zawartego w akcie normatywnym, aniżeli uzasadnioną i uzasadnianą decyzją stosowania prawa karnego" (K. Zeidler, P. Rybiński, Społeczna szkodliwość czynu przestępstwa przeciwko dziedzictwu kultury, w: M. Trzciński, O. Jakubowski (red.), Przestępstwa przeciwko dziedzictwu kulturowemu. Diagnoza, zapobieganie, zwalczanie, Katedra Kryminalistyki, Wydział Prawa, Administracji i Ekonomii Uniwersytetu Wrocławskiego, Wrocław 2016, s. 261).
} 
czy nie. Natomiast każdy sędzia respektując (miejmy nadzieję) wolę ustawodawcy w swej pracy, kieruje się własnymi przekonaniami i wartościami i też ma swoje poglądy na zasadność ścigania danej kategorii przestępstw w ogóle. Należy również zwrócić uwagę na przyzwyczajenie sądów do potwierdzania woli oskarżyciela publicznego ${ }^{31}$ (nakazy karne itp.). Zatem jeśli oskarżyciel publiczny - prokurator - nie chce ścigać przestępstwa, to wojewódzki konserwator zabytków ma szanse na przekonanie sądu do swoich racji w trybie zażalenia (choć ciekawe byłoby prześledzenie statystyk, ile zażaleń wnosi się rocznie w skali kraju i ile z tych zażaleń było skutecznych ${ }^{32}$ ). Inny jest odbiór społeczny wyroku skazującego, inny nadzwyczajnego złagodzenia kary, a nawet umorzenia w toku postępowania, a inny jest wymiar społeczny „zlikwidowania” postępowania karnego, zanim się jeszcze na dobre zaczęło.

Ważną przesłanką skuteczności czynności organów ścigania jest powszechna akceptacja pracowników tych organów stosowania ingerencji państwowej w określonej dziedzinie regulowanej prawem. „Leges sine moribus vanae - prawo jest bezsilne, jeśli nie znajduje oparcia w moralności czy w nawykach społeczeństwa"33. Czynnik ludzki odgrywa tu kluczową rolę i albo będzie działał w kierunku wskazanym przez ustawodawcę, albo będzie szukał możliwości unikania działania, stosując np. klauzulę znikomego stopnia społecznej szkodliwości czynu i tak naprawdę legalizując swoje osobiste poglądy na karalność danego czynu w ogóle.

Jednocześnie należy zwrócić uwagę na to, że sposób postrzegania przestępstw przeciwko zabytkom ${ }^{34}$ lub realne możliwości ścigania przestępstw i wykroczeń przez niedostosowaną do tych zadań strukturę administracyjną rzutują na wynik postępowania. Przykładowo, wojewódzki urząd ochrony zabytków jest strukturą skupiającą w swoich szeregach przeważnie pracowników o wykształce-

31 O niepisanej zasadzie "policjant ma zawsze rację” szerzej zob. w: T. Sienkiewicz, Zasada prawdy materialnej w postępowaniu w sprawach o wykroczenia. Studium jednego przypadku, „Studia Prawnicze KUL” 2011, nr 3-4.

32 Na przykład Ministerstwo Kultury i Ochrony Dziedzictwa Narodowego nie prowadzi statystyk lub jakiejś formy ewidencji spraw karnych, które zostały wszczęte przez zawiadomienie o popełnieniu przestępstwa lub o podejrzeniu popełnienia przestępstwa, gdy zawiadamiającym jest wojewódzki konserwator zabytków lub inny podmiot publiczny mający związek z ochroną zabytków, ani sytuacji, w których pomimo zawiadomienia o przestępstwie lub podejrzeniu popełnienia przestępstwa, gdy zawiadamiającym jest wojewódzki konserwator zabytków lub inny podmiot publiczny mający związek z ochroną zabytków, wydawane jest postanowienie o odmowie wszczęcia dochodzenia. Zob. pismo Ministerstwa Kultury i Ochrony Dziedzictwa Narodowego z dnia 12.07.2017 r., znak: CI-WIP.0111.205.2017.IJ, niepublikowane.

33 Z. Ziembiński, Zarys zagadnień etyki, Edytor, Poznań - Toruń 1994, s. 110.

34 O stosunku wymiaru sprawiedliwości do przestępstw względem zabytków pisał również Kamil Zeidler w artykule Nowe przestępstwa w systemie karnoprawnej ochrony dziedzictwa kultury, "Ochrona Zabytków” 2006, nr 4, s. 67: „W praktyce wymiar sprawiedliwości traktuje, niesłusznie, przestępstwa pozakodeksowe za mniej ważne. Nic nie uzasadnia poglądu, że skoro zostały one umieszczone poza kodeksem karnym, to ich szkodliwość społeczna jest niższa. Zniszczenie dobra kultury jest przestępstwem o niewątpliwie wysokiej społecznej szkodliwości, a zwłaszcza, gdy dotyka bezcennych i unikatowych dzieł sztuki lub zabytków skarbów narodowych". 
niu w zakresie archeologii, historii sztuki lub architektury, niemającą specjalistów w zakresie ścigania czynów zabronionych. Przeważnie pracownikiem, który ma pełne pojęcie o tych zadaniach, jest radca prawny zatrudniony w urzędzie. $Z$ tego powodu przypisywanie przez ustawodawcę możliwości występowania w procesie jako - odpowiednio - oskarżyciel publiczny lub posiłkowy w aktualnym stanie struktur urzędniczych obsługujących to zadanie mija się z celem, gdyż np. wojewódzki urząd ochrony zabytków nie ma takich możliwości zbierania informacji jak prokuratura lub Policja.

Urząd w zasadzie de facto dysponuje tylko tymi danymi, które uda mu się zgromadzić $\mathrm{w}$ trakcie czynności administracyjno-kontrolnych prowadzonych wobec posiadacza zabytku, i jeśli w trakcie tych czynności okaże się, że czyn wypełnia przesłanki czynu zabronionego, a sprawca jest znany lub możliwy do ustalenia przez urząd, wówczas można mówić o wstępnym sukcesie podczas formułowania np. wniosku o ukaranie. W bardziej skomplikowanych przypadkach niezbędna będzie pomoc prokuratury, która z kolei może odnosić się niezbyt chętnie (jako również struktura administracyjna) do realizacji zadań, jakie ustawodawca postawił przed innym organem, choć kompetencje nie są identyczne. Jednocześnie ustawodawca nie przewidział możliwości karania $w$ formie mandatu karnego sprawców drobnych wykroczeń, np. zawieszających reklamy na zabytkach nieruchomych, wpisanych do rejestru, bez pozwolenia. Za każdym razem, gdy występuje potrzeba ukarania sprawcy w przypadku stwierdzenia nawet oczywistego wykroczenia, aby nastąpiło ukaranie, sprawa musi trafić do sądu. Oczywiście nie w każdym przypadku wykroczenia należy sporządzać wniosek o ukaranie, a zawsze należy brać pod uwagę możliwość zastosowania środków oddziaływania wychowawczego wskazanych w Kodeksie wykroczeń ${ }^{35}$ (dalej: k.w.). Wymierzenie kary lub wymuszanie postępowania zgodnego z prawem wskutek egzekucji administracyjnej stanowi ostateczne rozwiązanie „siłowe" i jest często świadectwem niewielkiej skuteczności dotychczas stosowanych przez urząd środków nadzoru lub braku woli współpracy dysponenta zabytku $z$ urzędem. W opinii autora stanowi ostateczność w aspekcie regulowanej materii. Znacznie lepsze efekty $w$ ochronie zabytków będzie miało przekonanie o działaniu we wspólnym celu zarówno właściciela zabytku, jak i administracji, niż przymuszanie podmiotu podporządkowanego w stosunku administracyjnoprawnym do wykonania obowiązku za pomocą rozwiązań siłowych. Nie zmienia to jednak poglądu autora o tym, że przy próbie stosowania sankcji w ochronie zabytków system norm dotyczący tych postępowań nie jest zadowalająco sprawiedliwy i skuteczny, a jest to związane z utrudnionym realizowaniem zasady prawdy materialnej w tych postępowaniach.

35 Ustawa z dnia 20 maja 1971 r. Kodeks wykroczeń, tekst jedn. Dz. U. z 2015 r., poz. 1094 ze zm. 
W tej sytuacji należy - za Markiem Bojarskim i Wojciechem Radeckim - postawić trzy istotne pytania:

1. Czy zamachy na zabytki powinny być ścigane jako przestępstwa, czy jako wykroczenia?

2. Jak powinny być ujęte znamiona przestępstw i wykroczeń?

3. Gdzie jest miejsce przepisów karnych o ochronie zabytków, w kodeksach czy w ustawie specjalnej?36

Istnieją w doktrynie poglądy świadczące o przekonaniu powiązania umiejscowienia przestępstwa ze skutecznością ich ścigania. Być może organy ścigania traktują przestępstwa wskazane w Kodeksie karnym jako "swój zakres działania”, a pozakodeksowe traktują z mniejszym natężeniem woli ścigania. Umiejscowienie przepisu w Kodeksie karnym może być traktowane na równi z czynem bardziej szkodliwym społecznie niż umieszczenie poza tym Kodeksem. Kamil Zeidler pisze:

Niestety, praktyka wymiaru sprawiedliwości jest taka, że przestępstwa pozakodeksowe są uznawane, zupełnie niesłusznie, za mniej ważne. Niczym nieuzasadnione jest potoczne przekonanie, że skoro zostały one umieszczone poza kodeksem karnym, to ich społeczna szkodliwość jest niższa ${ }^{37}$.

\section{Olgierd Jakubowski wyraża następujący pogląd:}

Przekonujące są dla mnie argumenty dotyczące stworzenia w kodeksie karnym rozdziału, do którego zostałyby przeniesione przepisy karne z ustawy z 2003 r. o ochronie zabytków i opiece nad zabytkami. Wśród nich należy wskazać w szczególności: [...]. Zwiększenie znajomości wyżej wymienionych przepisów wśród prokuratorów, sędziów, adwokatów oraz reszty społeczeństwa, co pełniłoby również funkcję prewencyjną - obecna świadomość przepisów karnych z ustawy o ochronie zabytków i opiece nad zabytkami jest w mojej opinii niewystarczająca. [...] Zmiany w systemie karnoprawnej ochrony zabytków są konieczne, by cały system ochrony dziedzictwa w Polsce funkcjonował prawidłowo. Odpowiedni nowy rozdział w kodeksie karnym z prawidłowo skonstruowanymi przepisami karnymi może zmienić postrzeganie tego zjawiska przez sędziów i prokuratorów ${ }^{38}$.

Stosowanie norm karnych i wykroczeniowych w sytuacjach związanych z zabytkami napotyka na liczne trudności. Jedną z nich jest przygotowanie merytoryczne pracowników organów powołanych do ścigania tych specyficznych prze-

36 M. Bojarski, W. Radecki, Ochrona zabytków w polskim prawie karnym. Stan aktualny i propozycje de lege ferenda, w: J. Kaczmarek (red.), Prawnokarna ochrona dziedzictwa kultury. Materiały z konferencji Gdańsk, 30 maja - 1 czerwca 2005 r., Zakamycze, Kraków 2006, s. 13.

37 K. Zeidler, Karnoprawna ochrona zabytków, w: K. Zeidler, K. Zalasińska, Wykład prawa ochrony zabytków, Wolters Kluwer, Wydawnictwo Uniwersytetu Gdańskiego, Warszawa - Gdańsk 2015, s. 164.

38 O. Jakubowski, Karnoprawna ochrona zabytków - rozważania nad kierunkami zmian prawnych, w: K. Zeidler (red.), Prawo ochrony zabytków, Wolters Kluwer, Wydawnictwo Uniwersytetu Gdańskiego, Warszawa - Gdańsk 2014, s. 483. 
stępstw i wykroczeń. M. Bojarski i W. Radecki krytycznie wypowiadają się o stosowaniu, a w zasadzie niestosowaniu norm karnych pozakodeksowych:

Byłoby lepiej, gdyby interpretacją przepisów karnych z dziedziny ochrony zabytków zajmowali się specjaliści prawa karnego niż specjaliści prawa ochrony zabytków, ci ostatni bowiem zazwyczaj nie mają nie tyle umiejętności, co chęci korzystania z dorobku nauk penalnych. Najprostszą drogą prowadzącą do tego byłoby włączenie przepisów o przestępstwach przeciwko zabytkom do podstawowego źródła prawa karnego materialnego, jakim jest kodeks karny ${ }^{39}$.

Wydaje się jednak, że samo tylko włączenie do kodeksu nie jest sposobem na likwidację nieprawidłowości w tym zakresie. Wprowadzenie tych norm do Kodeksu karnego nie załatwi całościowo problemu, gdyż nadal pozostaje przekonanie poszczególnych funkcjonariuszy organów ścigania o słuszności (lub braku słuszności) ścigania. Janusz Sługocki pisze:

Obecny - krytyczny - stan zabytków w Polsce jest oczywiście spowodowany nie tylko uwarunkowaniami prawnymi, ale też często ich destruktywna rola nie jest powszechnie znana. Szczególnie, gdy niedoskonałości ustawodawstwa idą w parze z niewłaściwym działaniem instytucji publicznych. [...] W mojej ocenie największym zagrożeniem dla sprawowania właściwej lub choćby poprawnej opieki nad zabytkiem jest pozorna ochrona sprawowana przez urzędników, którzy z różnych powodów są w stanie bez oporów poświęcić dobro zabytków dla innych celów ${ }^{40}$.

Urzędnicy, funkcjonariusze publiczni, policjanci, prokuratorzy, sędziowie itd., niezależnie od nazwy - osoby wykonujące różne funkcje w strukturach publicznych, identyfikują się z ustawowym celem działania struktury lub nie. Poszczególne struktury mogą traktować niektóre kompetencje jako „swoje” - należące do katalogu norm, którymi trzeba się zajmować lub nie. Na tle tych uwag pojawia się pytanie: czy winą za niestosowanie norm sankcjonujących czyny zabronione $w$ formie karnej można obarczyć tylko pracowników służb ochrony zabytków, przypisując im cechę braku woli lub nieumiejętność działania? Byłoby to nietrafne spostrzeżenie - zdaniem autora.

Wątpliwości budzą się również przy ocenie materiału dowodowego i rozstrzyganiu o zaistnieniu przestępstwa przez profesjonalnie do tego przygotowane organa ścigania. Jako kolejny przykład można podać sprawę zniszczenia zabytkowego domu. Należy przywołać tu postanowienie Prokuratora Prokuratury Rejonowej w Opolu Lubelskim w sprawie prowadzonej pod sygn. akt Ds/1673/12 o umorzeniu dochodzenia ${ }^{41}$. Wątpliwości budzi ocena stanu faktycznego i prawnego, polegająca na przyjęciu znikomej szkodliwości społecznej w sytuacji zniszczenia drewnianego

39 M. Bojarski, W. Radecki, op. cit., s. 28-29.

40 J. Sługocki, Opieka nad zabytkiem nieruchomym. Problemy administracyjnoprawne, Wolters Kluwer, Warszawa 2014, s. 173.

41 Zob. T. Sienkiewicz, Pozwolenie..., s. 132-134. 


\section{ANALIZY PRAWNE}

Tomasz Sienkiewicz

domu, zabytku wpisanego do rejestru zabytków. Wojewódzki konserwator zabytków może w sprawach ochrony zabytków występować na prawach oskarżyciela posiłkowego w postępowaniu karnym, na podstawie art. 95 pkt 2 u.o.z. W związku z obowiązkiem wskazanym w art. 304 k.p.k. zawiadomiono Prokuraturę Rejonową w Opolu Lubelskim o podejrzeniu popełnienia przestępstwa określonego w art. 108 ust. 1 u.o.z. Czyn zabroniony polegał na zniszczeniu zabytku wpisanego do rejestru zabytków - domu drewnianego. Stwierdzenie przez prokuratora, że społeczna szkodliwość czynu polegającego na zniszczeniu drewnianego domu wpisanego do rejestru zabytków jest znikoma, jest oceną mogącą rodzić wątpliwości w świetle samych prawnych aspektów ochrony zabytków. Wpis do rejestru zabytków jest, zgodnie z art. 7 u.o.z., formą ochrony zabytków. Zgodnie z art. 4 u.o.z., ochrona zabytków polega m.in. na udaremnianiu ich niszczenia. Ochrona w wymiarze społecznym realizowana jest także poprzez sankcje karne wskazane w tej ustawie. Rezygnacja ze ścigania w takiej sytuacji, jaką jest zniszczenie domu wpisanego indywidualnie do rejestru zabytków, pozbawia normy prawne ich oddziaływania społecznego w pożądanym przez ustawodawcę kierunku. Strzeżenie dziedzictwa narodowego jest obowiązkiem, do wykonania którego zobowiązuje administrację publiczną Konstytucja RP w art. 5. Z samej definicji zabytku wskazanej w art. 3 pkt 1 u.o.z. wynika, że zachowanie ich „leży w interesie społecznym ze względu na posiadaną wartość historyczną, artystyczną lub naukową". Wpis do rejestru zabytków następuje po postępowaniu administracyjnym, w ramach którego badane jest to, czy takie przesłanki zachodzą. Jeżeli zabytek zostanie wpisany do rejestru zabytków, należy przyjąć, że jego zachowanie leży w interesie społecznym. Nielegalne działania niszczące zabytek, sprzeczne z interesem społecznym, powinny spotkać się z reakcją organów ścigania. O prawnym znaczeniu wpisu do rejestru zabytków świadczy fakt, że skreślenie z rejestru następuje na podstawie decyzji ministra właściwego do spraw kultury i ochrony dziedzictwa narodowego (art. 13 ust. 5 u.o.z.). Z samych prawnych aspektów wpisu do rejestru zabytków wynika, że obiekt wpisany do tego rejestru ma na tyle istotne wartości chronione prawem, że w interesie społecznym obiekt ten powinien być chroniony przed fizycznym zniszczeniem. Już choćby z tego powodu argumentacja prokuratora o znikomej szkodliwości społecznej czynu, nie przesądzając, czy słuszna (czy nie), na tle tych prawnych uwarunkowań jest mało przekonująca, gdyż do rejestru zabytków wpisywane są obiekty o wartości społecznej najczęściej większej niż znikomej - historycznej, artystycznej lub naukowej ${ }^{42}$.

Skoro sytuację zniszczenia zabytkowego budynku można potraktować jako znikomą szkodliwość społeczną, to tym bardziej pozornie „mniej ważne i wartościowe" obiekty jeszcze niewpisane do rejestru zabytków (choć mogą być zabytkami w świetle ustawowej definicji zabytku). Warto przypomnieć, że zabytki chronione są z uwagi na interes społeczny, wskazany w ustawowej definicji zabytku.

42 Por. ibidem. 
Społeczeństwo czasem domaga się działania od organów do tego upoważnionych, za pośrednictwem np. stowarzyszeń, fundacji czy indywidualnych działań osób fizycznych. Przykładowo, do Wojewódzkiego Urzędu Ochrony Zabytków w Lublinie wpłynął wniosek pewnej fundacji o wpisanie do rejestru zabytków województwa lubelskiego piwnic po byłych katowniach UB i NKWD mieszczących się w kilku budynkach w Lublinie. Jak wynikało z wniosku, w piwnicach tych znajdują się inskrypcje wyryte przez więźniów przetrzymywanych tam w latach 1944-1954. Pismo to zawierało informację, że inskrypcje są niszczone oraz że planowane jest dalsze usunięcie ich części. Zgodnie z art. 108 ust. 1 u.o.z., kto niszczy lub uszkadza zabytek, podlega karze pozbawienia wolności od 3 miesięcy do lat 5 . Jest to przestępstwo ścigane z urzędu. Ochronie i opiece podlegają, bez względu na stan zachowania, również miejsca upamiętniające wydarzenia historyczne (art. 6 ust. 1 pkt 1 lit. h u.o.z.). LWKZ zawiadomił Komendanta Wojewódzkiego Policji w Lublinie o podejrzeniu popełnienia przestępstwa pismem z dnia 14.04.2016 r. ${ }^{43}$ Komisariat I Policji w Lublinie wystosował pismo z dnia 1.05.2016 r. do Wojewódzkiego Urzędu Ochrony Zabytków, prosząc o wyznaczenie i spowodowanie stawiennictwa w komisariacie

uprawnionej osoby do złożenia zawiadomienia i przesłuchania w charakterze osoby zawiadamiającej na okoliczności:

- Na jakim etapie jest obecnie postępowanie z wniosku Fundacji [...] o wpisanie do rejestru zabytków piwnic [...].

- Sprecyzowania dokładnej lokalizacji przedmiotowych piwnic, ilości piwnic, a także wskazanie jakiego charakteru są to inskrypcje, czy w tych piwnicach znajdują się oryginalne kraty, oryginalne drzwi do cel więziennych z lat 40-tych i 50-tych XX wieku, a także wskazanie danych osób do których obecnie te piwnice należą, ze wskazaniem właścicieli nieruchomości.

- Czy właściciele piwnic oficjalnie byli informowani o zabytkowym charakterze znajdujących się tam inskrypcji i trwającym postępowaniu o wpisanie do rejestru zabytków województwa Lubelskiego piwnic we wskazanych kamienicach [...] jeżeli tak, to kiedy.

- Kiedy zostały rozpoczęte remonty piwnic, które piwnice zostały wyremontowane i przez kogo, do kogo należą te piwnice.

- Wskazanie lokalizacji piwnic i właścicieli którzy zniszczyli inskrypcje.

- Wskazanie osób planujących generalny remont w/w kamienic ${ }^{44}$.

Oczekiwanie od wojewódzkiego konserwatora zabytków wiedzy o przestępstwie w zakresie, który może być ustalony w trybie przewidzianym dla postępowania karnego (a w zasadzie postępowania przygotowawczego), może nie zakończyć się sukcesem. 30 maja 2016 r. wydano postanowienie o odmowie wszczęcia docho-

\footnotetext{
43 Zawiadomienie o podejrzeniu popełnienia przestępstwa skierowane przez LWKZ do Komendanta Wojewódzkiego Policji w Lublinie z dnia 14.04.2016 r., znak: KD.5140.9.2.2016, niepublikowane.

44 Pismo Komisariatu I Policji w Lublinie do Wojewódzkiego Urzędu Ochrony Zabytków w Lublinie z dnia 1.05.2016 r., L.Dz. 4375/16, Nr L2623, niepublikowane.
} 


\section{ANALIZY PRAWNE}

Tomasz Sienkiewicz

dzenia „z uwagi na brak znamion czynu zabronionego - art. $17 \S 1$ pkt 2 kpk"45 (czyn nie zawiera znamion czynu zabronionego albo ustawa stanowi, że sprawca nie popełnia przestępstwa). Żadna ustawa nie zastąpi woli ścigania organów ścigania.

Problem uchylania się od ścigania sprawców czynów zabronionych nie dotyczy tylko przestępstw. Kolejnym przykładem na brak konsekwencji w ściganiu czynów zabronionych przeciwko zabytkom jest sprawa dotycząca wykroczenia polegającego na niezabezpieczeniu zabytku przed zniszczeniem w sprawie prowadzonej przez Komendę Powiatową Policji w Puławach pod sygn. akt RSoW-1277/12. W związku z obowiązkiem wskazanym w art. 304 k.p.k. wojewódzki konserwator zabytków zawiadomił Prokuraturę Rejonową w Puławach o podejrzeniu popełnienia przestępstwa określonego $w$ art. 108 ust. 1 u.o.z. lub wykroczenia $z$ art. 110 ust. 1 u.o.z. Czyn zabroniony polegał na niszczeniu oraz niezabezpieczeniu zabytku wpisanego do rejestru zabytków - oranżerii. Prokuratura odmówiła wszczęcia dochodzenia w sprawie o przestępstwo z art. 108 ust. 1 u.o.z. Następnie Komenda Powiatowa Policji w Puławach zawiadomieniem z dnia 4.12.2012 r. poinformowała o tym, że czynności wyjaśniające nie dostarczyły podstaw do skierowania wniosku o ukaranie do sądu rejonowego (doręczone 7.12.2012 r.) ${ }^{46}$. Stwierdzenie przez Komendą Powiatową Policji w Puławach, że czynności wyjaśniające nie dostarczyły podstaw do wniesienia wniosku o ukaranie, budzi wątpliwości co do prowadzenia tych czynności zgodnie z zasadą prawdy materialnej. Wykroczenie z art. 110 u.o.z. polega na braku właściwej opieki nad zabytkiem. Zgodnie z jego treścią, kto będąc właścicielem lub posiadaczem zabytku nie zabezpieczył go w należyty sposób przed uszkodzeniem, zniszczeniem, zaginięciem lub kradzieżą, podlega karze aresztu, ograniczenia wolności albo grzywny. Zatem do roli Policji przede wszystkim należało ustalenie właściciela lub posiadacza zabytku odpowiedzialnego za opiekę nad nim, a także tego, czy ich opieka zabezpieczała należycie zabytek przed uszkodzeniem. To fizyczne niszczenie zostało ujawnione w postępowaniu administracyjnym i było powodem zawiadomienia. Już choćby z tego powodu czynności wyjaśniające powinny zmierzać do ustalenia zakresu odpowiedzialności za zabytek - posiadacza lub właściciela (oba podmioty ujawnione) oraz tego, czy ich opieka zabezpieczała należycie zabytek przed niszczeniem. Do rejestru zabytków wpisywane są obiekty o wartości społecznej najczęściej większej niż znikomej - historycznej, artystycznej lub naukowej. $Z$ tego powodu motywowanie podmiotów odpowiedzialnych za opiekę nad zabytkiem do zabezpieczania go przed uszkodzeniem jest zasadne.

$\mathrm{Na}$ tych przykładach widać, jak wiele czynników sprawia, że normy o charakterze karnym w ochronie zabytków nie znajdują właściwej realizacji. Stan faktyczny w tych sprawach wymaga dogłębnej analizy oraz wiedzy i w zakresie nauk karnych,

45 Postanowienie o odmowie wszczęcia dochodzenia wydane przez Komisariat I Policji w Lublinie z dnia 30.05.2016 r., L.Dz. 4375/16, RPS 299/16, Nr L3302, niepublikowane.

46 Pismo Komendy Powiatowej Policji w Puławach z dnia 4.12.2012 r., sygn. akt RSoW-1277/12, niepublikowane. 
i w zakresie historii sztuki, architektury itp. Jest to wyjątkowo trudne zadanie, skoro od wielu lat istnieje problem sankcjonowania tego rodzaju czynów zabronionych. Konieczna jest zatem zmiana kultury organizacyjno-prawnej organów ścigania w zakresie ochrony zabytków. Jest to jednak materiał na odrębną monografię w tym $z_{\text {zakresie }}{ }^{47}$. Na marginesie należy odnotować, że niedostateczne realizowanie sankcji o charakterze karnym nie stanowi tylko cechy czasów obecnych. Władysław Sieroszewski w 1971 r. wskazywał zjawiska podobne ${ }^{48}$. Warto więc zauważyć szczególną formę zażalenia na postanowienie o odmowie wszczęcia dochodzenia jako czynności o charakterze edukacyjnym wobec organów ścigania. Samo wszczęcie postępowania (karnego lub w sprawie o wykroczenie), niezależnie od jego zakończenia, to już jest (często pozorny) sukces wojewódzkiego konserwatora zabytków, który ujawnił czyn zabroniony w trakcie swojej działalności. Wskazane wyżej przykłady przerywania różnych postępowań na różnych ich etapach stanowią ilustrację tezy o zasadności docenienia instytucji zażalenia w działalności wojewódzkiego konserwatora zabytków, zwłaszcza zażalenia na postanowienie o odmowie wszczęcia dochodzenia, gdy konserwator ten w trybie art. 304 k.p.k sam zawiadamia o podejrzeniu popełnienia przestępstwa - co oznacza, że wstępna analiza sytuacji została przeprowadzona i prawdopodobieństwo popełnienia czynu zabronionego występuje. Ochrona zabytków wymaga, by sprawcy przestępstw wskazanych w ustawie o ochronie zabytków i opiece nad zabytkami częściej musieli zastanowić się nad swoim działaniem, przynajmniej w charakterze podejrzanego, jeśli nie oskarżonego.

47 Por. np. M. Trzciński, Przestępczość przeciwko zabytkom archeologicznym. Problematyka prawno-kryminalistyczna, Wolters Kluwer Polska, Warszawa 2010.

48 „Z chwilą, kiedy znaczna część zabytków - w tym większość zabytków nieruchomych - stała się własnością społeczną, a i te, które pozostały w rękach osób prywatnych stanowią dobytek kulturalny ogólno-narodowy, powstała konieczność daleko idącego zaostrzenia sankcji za przestępstwa przeciwko ich ochronie. Temu wydatnemu zaostrzeniu sankcji karnych nie towarzyszyły jednak w praktyce surowsza represja tych przestępstw przez sądy i organy ścigania. Rozprawy sądowe w tego rodzaju sprawach należą do rzadkości. Byłby to objaw pomyślny, gdyby odzwierciedlał stan faktyczny w naszym kraju. Niestety jednak wypadki naruszania przepisów o ochronie dóbr kultury zdarzają się bardzo często, a sprawcami bywają nie tylko osoby prywatne, ale i przedstawiciele niektórych organów administracji państwowej, zwłaszcza jeżeli chodzi o nielegalne rozbiórki lub przebudowy obiektów zabytkowych. Dowodzi to, że idea ochrony dóbr kultury nie przeniknęła głęboko w szeregi naszego społeczeństwa. Przestępstwa przeciwko niej są zbyt często uznawane za mało ważne i cieszą się przywilejem «z powodu niewielkiej szkodliwości społecznej czynu». A jeżeli nawet trafią do sądu, to kończą się na ogół wyrokiem z zawieszeniem kary. Wyjątek stanowią sprawy o nielegalny wywóz dóbr kultury za granicę. Przestępstwo to - trudne zresztą, jak każdy przemyt, do uchwycenia mimo czujności organów celnych - ulega na ogół surowej represji. Wiąże się ono zresztą zwykle z innymi przestępstwami o charakterze przeważnie karno-skarbowym.

Część winy za niewykorzystanie możliwości prawnych, jakie daje Ustawa, ponoszą i organy służby konserwatorskiej, które niechętnie i dopiero w ostateczności kierują sprawę na drogę postępowania karnego w przekonaniu - niestety częściowo uzasadnionym - «że i tak nic z tego nie będzie». Organy te często nie umieją wykorzystać środków prawnych, jakie im przysługują w toku postępowania karnego z powodu braku należytej współpracy ze strony obsługi prawnej prezydiów rad narodowych" (W. Sieroszewski, Ochrona prawna dóbr kultury w Polsce, Ministerstwo Kultury i Sztuki. Zarząd Muzeów i Ochrony Zabytków, Warszawa 1971, s. 114-115). O historii przepisów karnych o ochronie zabytków zob. M. Bojarski, W. Radecki, op. cit., s. 13 i n. 


\section{Wnioski końcowe}

1. Leges sine moribus vanae - nie da się działać w zakresie ochrony zabytków w sposób skuteczny, jeśli funkcjonariusze organów ścigania nie identyfikują celów swojego działania z celem ustawodawcy.

2. Postawa sądu determinuje stanowisko prokuratury i Policji - jeśli w danym sądzie nie ma zrozumienia dla idei ochrony zabytków, często próżno szukać zrozumienia tej idei wśród osób, od których postanowień zażalenie będzie kierowane do sądu. Konstytucyjnie określony obowiązek strzeżenia dziedzictwa narodowego (art. 5) jest obowiązkiem również sądu, prokuratury i Policji.

3. Ustanowienie wojewódzkiego konserwatora zabytków jako działającego na prawach oskarżyciela posiłkowego w postępowaniu karnym (w stanie prawnym sprzed omawianej wyżej nowelizacji) i w konsekwencji uzależnienie jego działania od stanowiska organów ścigania mogących skutecznie wnieść samodzielnie akt oskarżenia powodowały utrudnienie realizacji norm karnych, a wojewódzki konserwator zabytków stawał się organem realizującym głównie obowiązek zawiadomienia o przestępstwie $z$ art. 304 k.p.k. oraz uprawnienie do złożenia zażalenia z art. 306 § 1 pkt 2 k.p.k. ewentualnie wnoszącego o podjęcie czynności w trybie 327 $\S 1$ k.p.k. Zdaniem autora niniejszego artykułu, nowe brzmienie art. 95 u.o.z. nie rozwiąże szybko problemu, gdyż „nowe” prawo otrzymała do stosowania struktura stosująca w określony sposób dotychczasowe przepisy (policyjna, prokuratorska, sądowa), przyzwyczajona do konkretnej kultury stosowania prawa, a kultura ta nie sprzyjała stosowaniu norm karnych związanych z ochroną zabytków. Również wojewódzki konserwator zabytków będzie musiał stopniowo dostosować się do nowych możliwości prawnych. Radykalne szybkie zmiany raczej nie nastąpią - będzie to dłuższy proces.

4. Zażalenie na postanowienie o odmowie wszczęcia dochodzenia z art. 306 $\S 1$ pkt 2 k.p.k. jest jedną z podstawowych prawnych form działania wojewódzkiego konserwatora zabytków w sprawach karnych, który może w ten sposób przekazać organom ścigania swoje poglądy na szkodliwość społeczną przestępstw wskazanych w ustawie o ochronie zabytków i opiece nad zabytkami.

\section{Bibliografia}

Bojarski M., Radecki W., Ochrona zabytków w polskim prawie karnym. Stan aktualny i propozycje de lege ferenda, w: J. Kaczmarek (red.), Prawnokarna ochrona dziedzictwa kultury. Materiały z konferencji Gdańsk, 30 maja - 1 czerwca 2005 r., Zakamycze, Kraków 2006.

Dębiński A., Prawo rzymskie jako podstawa kultury europejskiej, w: A. Dębiński, L. Pietraszko (red.), Ochrona dziedzictwa kulturowego i materialnego pogranicza, Wydawnictwo KUL, Lublin 2011. 
Zażalenie na postanowienie o odmowie wszczęcia dochodzenia...

Complaint against the decision on refusal to institute an investigation...

Drela M., Własność zabytków, C.H. Beck, Warszawa 2006.

Jagielska-Burduk A., Zabytek ruchomy, Wolters Kluwer Polska, Warszawa 2011.

Jakubowski O., Karnoprawna ochrona zabytków - rozważania nad kierunkami zmian prawnych, w: K. Zeidler (red.), Prawo ochrony zabytków, Wolters Kluwer, Wydawnictwo Uniwersytetu Gdańskiego, Warszawa - Gdańsk 2014.

Jakubowski O., Zagrożenie dziedzictwa kulturowego przestępczością - analiza wydarzeń z 2015 roku, „Santander Art. \& Culture Law Review” 2016, nr 1(2).

Jednorazowe pozwolenie na czasowy wywóz zabytku za granicę nr 3/2012, z dnia 12.10.2012 r., znak IR.5175.4.1.2012 wydane przez LWKZ, niepublikowane.

Klat-Wertelecka L., Problemy graniczne w postępowaniu egzekucyjnym w administracji, w: S. Wrzosek, M. Domagała, J. Izdebski, T. Stanisławski, (red.), Przegląd dyscyplin badawczych pokrewnych nauce prawa i postępowania administracyjnego. Zjazd Katedr Prawa Administracyjnego i Postępowania Administracyjnego Kazimierz Dolny nad Wisłą, 19-22 września 2010 r., Wydawnictwo KUL, Lublin 2010.

Łukasiewicz J., Prawne uwarunkowania skuteczności działania administracji publicznej, Wydawnictwo UMCS, Lublin 1990.

Paczuski W., Wywóz zabytku za granicę, w: K. Zeidler (red.), Leksykon prawa ochrony zabytków, 100 podstawowych pojęć, C.H. Beck, Warszawa 2010.

Pismo Komendy Powiatowej Policji w Puławach z dnia 4.12.2012 r., sygn. akt RSoW-1277/12, niepublikowane.

Pismo Komisariatu I Policji w Lublinie do Wojewódzkiego Urzędu Ochrony Zabytków w Lublinie z dnia 19.11.2015 r., L.Dz. 11577/15, niepublikowane.

Pismo Komisariatu I Policji w Lublinie do Wojewódzkiego Urzędu Ochrony Zabytków w Lublinie z dnia 1.05.2016 r., L.Dz. 4375/16, Nr L2623, niepublikowane.

Pismo LWKZ z dnia 9.11.2015 r., znak: IR.5175.7.2.2015, niepublikowane.

Pismo Ministerstwa Kultury i Ochrony Dziedzictwa Narodowego z dnia 12.07.2017 r., znak: CI-WIP.0111.205.2017.IJ, niepublikowane.

Postanowienie o odmowie wszczęcia dochodzenia wydane przez Komendę Powiatową Policji Świdnik z dnia 15.12.2015 r., RCS-571-15, Ds. 2029/15, niepublikowane.

Postanowienie o odmowie wszczęcia dochodzenia wydane przez Komisariat I Policji w Lublinie z dnia 30.05.2016 r., L.Dz. 4375/16, RPS 299/16, Nr L3302, niepublikowane.

Postanowienie z dnia 3.03.2016 r. Sądu Rejonowego Lublin-Wschód w Lublinie II Wydział Karny z siedzibą w Świdniku, sygn. akt II Kp 13/16, niepublikowane.

Sienkiewicz T., Pozwolenie w ochronie zabytków, Wydawnictwo KUL, Lublin 2013.

Sienkiewicz T., Zasada prawdy materialnej w postępowaniu w sprawach o wykroczenia. Studium jednego przypadku, „Studia Prawnicze KUL” 2011, nr 3-4.

Sieroszewski W., Ochrona prawna dóbr kultury w Polsce, Ministerstwo Kultury i Sztuki. Zarząd Muzeów i Ochrony Zabytków, Warszawa 1971.

Sługocki J., Opieka nad zabytkiem nieruchomym. Problemy administracyjnoprawne, Wolters Kluwer, Warszawa 2014.

Supernat J., Instrumenty działania administracji publicznej. Studium z nauki administracji, Kolonia Limited, Wrocław 2003.

Trzciński M., Przestępczość przeciwko zabytkom archeologicznym. Problematyka prawno-kryminalistyczna, Wolters Kluwer Polska, Warszawa 2010. 


\section{ANALIZY PRAWNE}

Tomasz Sienkiewicz

Ustawa z dnia z dnia 23 kwietnia 1964 r. Kodeks cywilny, Dz. U. z 2016 r., poz. 380 ze zm.

Ustawa z dnia 20 maja 1971 r. Kodeks wykroczeń, tekst jedn. Dz. U. z 2015 r., poz. 1094 ze zm.

Ustawa z dnia 2 kwietnia 1997 r. Konstytucja Rzeczypospolitej Polskiej, Dz. U. Nr 78, poz. 483.

Ustawa z dnia 6 czerwca 1997 r. Kodeks karny, tekst jedn. Dz. U. z 2016 r., poz. 1137 ze zm.

Ustawa z dnia 6 czerwca 1997 r. Kodeks postępowania karnego, tekst jedn. Dz. U. z 2016 r., poz. 1749 ze zm.

Ustawa z dnia 23 lipca 2003 r. o ochronie zabytków i opiece nad zabytkami, tekst jedn. Dz. U. z 2014 r. poz. 1664 ze zm.

Ustawa z dnia 10 lipca 2015 r. o zmianie ustawy o ochronie zabytków i opiece nad zabytkami oraz ustawy o muzeach, Dz. U. z 2016 r., poz. 1330.

Ustawa z dnia 25 maja 2017 r. o restytucji narodowych dóbr kultury, Dz. U. poz. 1086.

Uzasadnienie postanowienia o odmowie wszczęcia dochodzenia wydane przez Komendę Powiatową Policji Świdnik z dnia 15.12.2015 r., RCS-571/15, Ds. 2029/15.

Zalasińska K., Prawna ochrona zabytków nieruchomych w Polsce, Wolters Kluwer Polska, Warszawa 2010.

Zawiadomienie Prokuratury Rejonowej w Świdniku z dnia 31.12.2015 r., skierowane do LWKZ, znak: Ds. 2238/15, niepublikowane.

Zawiadomienie o podejrzeniu popełnienia przestępstwa skierowane przez LWKZ do Komendanta Wojewódzkiego Policji w Lublinie z dnia 14.04.2016 r., znak: KD.5140.9.2.2016, niepublikowane.

Zawiadomienie o podejrzeniu przestępstwa ściganego z urzędu skierowane przez LWKZ do Prokuratury Rejonowej w Świdniku z dnia 9.11.2015 r., znak: IR.5175.7.1.2015, niepublikowane.

Zażalenie LWKZ na postanowienie o odmowie wszczęcia dochodzenia do Prokuratora Rejonowego w Świdniku z dnia 21.12.2015 r., znak: IR.5175.7.3.2015, niepublikowane.

Zeidler K., Karnoprawna ochrona zabytków, w: K. Zeidler, K. Zalasińska, Wykład prawa ochrony zabytków, Wolters Kluwer, Wydawnictwo Uniwersytetu Gdańskiego, Warszawa - Gdańsk 2015.

Zeidler K., Nowe przestępstwa w systemie karnoprawnej ochrony dziedzictwa kultury, „Ochrona Zabytków" 2006, nr 4.

Zeidler K., Rybiński P., Społeczna szkodliwość czynu przestępstwa przeciwko dziedzictwu kultury, w: M. Trzciński, O. Jakubowski (red.), Przestępstwa przeciwko dziedzictwu kulturowemu. Diagnoza, zapobieganie, zwalczanie, Katedra Kryminalistyki, Wydział Prawa, Administracji i Ekonomii Uniwersytetu Wrocławskiego, Wrocław 2016.

Ziembiński Z., Zarys zagadnień etyki, Edytor, Poznań - Toruń 1994.

Zoll A., Komentarz do art. 1 Kodeksu karnego. Stan prawny 1.08.2016 r., LEX [dostęp: 22.04.2017]. 